\title{
IMPACT OF FINANCIAL SOLVENCY ON STOCK RETURNS
}

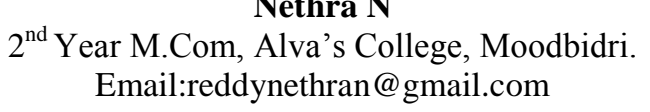

\section{Dr. Kushalappa. S}

Assistant Professor, Department of MBA, AIET, Mijar, Moodbidri.574225, Mob: 9686324188

Email: kushalkayarthadka@gmail.com

\begin{abstract}
Every investment is characterized by risk and return. For a common man, the term 'risk' means a situation in which something unpleasant/unexpected may happen. In other words, risk is a situation involving exposure to uncertainty. If the actual return obtained is same as the expected return, such an investment could be considered to be risk free, if the actual return obtained is less than the expected return, such an investment could be considered to be risky. Risk of an investment depends upon many factors. Risk would be avoidable or unavoidable. An investor by properly analysing the company, could reduce the company specific risks. Therefore, he has to study the strengths and weaknesses of the company in terms of its profitability, liquidity position, financial soundness, turnovers and etc. The focus of the present research is to identify the impact of financial soundness of the companies on its stock returns. Here the financial soundness of the companies is measure by using Althman's Z formula.
\end{abstract}

KEY WORDS: Return, risk, solvency

\section{INTRODUCTION}

Investment is a conscious act of an individual or any entity that involves deployment of funds in securities or assets issued by financial institution with a view to obtain target returns with specified period of time. Investment is characterized by risk and return. For a common man, the term 'risk' means a situation in which something unpleasant/unexpected may happen. In other words, risk is a situation involving exposure to uncertainty. If the actual return obtained is same as the expected return, such an investment could be considered to be risk free, if the actual return obtained is less than the expected return, such an investment could be considered to be risky. Risk can be broadly classified into two categories: Systematic risk and Unsystematic risk. Systematic risk is an uncontrollable risk, whereas, unsystematic risk or company specific risk is a controllable risk. The types of unsystematic risks are: business risk and financial risk. A business risk arises due to operational inefficiency of the firm and financial risk arises due to improper debt equity mix. Financially unsound company suffers from huge financial risk. Financial soundness of the company plays an important role in the investment decisions. Investors usually do not like stocks of financially weak companies. An attempt is 
made here to study the reaction of investors on companies with different financial soundness position. The focus of the research is to identify the impact of financial soundness of the companies on its stock returns. Here the financial soundness of the companies is measured by using Althman's $\mathrm{Z}$ formula.Altman- $\mathrm{Z}$ is the output of a credit-strength test that gauges a publicly traded manufacturing company's likelihood of bankruptcy. The Altman Z-score is based on five financial ratios that can be calculated from data found on a company's annual report. The Altman $\mathrm{Z}$ score can be calculated by the using this formula, $\mathrm{Z}=$ $1.2 \mathrm{~T}_{1}+1.4 \mathrm{~T}_{2}+3.3 \mathrm{~T}_{3}+0.6 \mathrm{~T}_{4}+$ 0.999T 5. Here, $\mathrm{T}_{1}=($ Current Assets Current Liabilities) $/$ Total Assets, $\mathrm{T}_{2}=$ Retained Earnings $/$ Total Assets, $\mathrm{T}_{3}=$ Earnings Before Interest and Taxes / Total Assets, $\mathrm{T}_{4}=$ Book Value of Equity $/$ Total Liabilities, The coefficients were estimated by identifying a set of firm's solvency position. Altman Z-score, can be used to evaluate both public and private companies, both manufacturing and nonmanufacturing companies. Investors can use Altman Zscores to help determine whether they should buy or sell a particular stock if they're concerned about the underlying company's financial strength.

\section{OBJECTIVES}

The main objective of the study is toevaluate the impact of financial soundness of the corporate on stock returns. In order to meet the main objective, the following specific objectives have been framed by the researchers:

- To create investment portfolios based on the Altman $\mathrm{Z}$ score of the companies

- To measure the performance of various portfolios constructed based on Altman Z score

- To identify the relationship between financial soundness of the companies and their performance in the stock market

- To offer meaningful suggestions to the investors based on the study

\section{SCOPE OF THE STUDY}

The study period is one year from March, 2013 to April, 2014. The companies chosen for the study are two companies each for each of the four portfolios. The companies are selected for each portfolio, based on the $\mathrm{Z}$ scores of the companies. The impact of the financial soundness on investors' 
attitudes is measured only by risk and returns of the securities. The conclusion is being drawn only on the basis of these two attributes.

\section{METHODOLOGY}

The entire study is based on secondary data extracted from various sources like books, websitees and other sources. The sample is selected from the BSE listed companies randomly. Then the AltmanZ score is calculated for the sample companies. Then the portfolio of two companies each is constructed based on the $\mathrm{Z}$ scores of the companies . The portfolios constructed are: 0.5 to $1 \mathrm{Z}$ score portfolio, 1 to $1.5 \mathrm{Z}$ score portfolio, 1.5 to $2 \mathrm{Z}$ score portfolio, 2 and above $\mathrm{Z}$ score portfolio. For each stock under each portfolio, the monthly returns are calculated from March, 2013 to April, 2014. Then the average return, standard deviation and coefficient of variance returns of each stock are calculated. Finally, the returns of each portfolio are calculated and then a comparison is made between the performances of each portfolio.

\section{LIMITATIONS OF THE STUDY}

- Since the entire study is based on secondary data, the study is not free from the limitations of secondary data.

- Altman Z score is calculated on the basis of various financial ratios, which are derived from financial statements of the companies under study. Therefore, the study also suffers from the limitations of financial statement.

- It is assumed that financial stability is the only factor affects the risk and returns of stocks under study

DATA ANALYSIS

AND

\section{INTERPRETATION}

Table 1: Risk-return profile of stocks of portfolio with 0 to $1 \mathrm{Z}$ value

\begin{tabular}{|c|c|c|}
\hline Month & $\begin{array}{c}\text { Neogem } \\
\text { India }\end{array}$ & $\begin{array}{c}\text { Ansal } \\
\text { Housing }\end{array}$ \\
\hline Mar-14 & -21.9417 & 3.560831 \\
\hline Feb-14 & -26.5335 & 6.309148 \\
\hline Jan-14 & -49.6408 & -17.6623 \\
\hline Dec-13 & 7.656613 & 4.054054 \\
\hline Nov-13 & -9.58042 & 8.695652 \\
\hline Oct-13 & -9.49367 & 19.94362 \\
\hline Sep-13 & 1.935484 & -5.08361 \\
\hline Aug-13 & 0 & 1.70068 \\
\hline Jul-13 & -4.90798 & -11.7117 \\
\hline Jun-13 & -4.95627 & -10.2426 \\
\hline May-13 & -3.65169 & 6 \\
\hline
\end{tabular}




\begin{tabular}{|c|c|c|}
\hline Apr-13 & -13.8015 & 5.740181 \\
\hline Average & $\mathbf{- 1 1 . 2 4 3}$ & $\mathbf{0 . 9 4 1 9 9 3}$ \\
\hline $\begin{array}{c}\text { Standard } \\
\text { Deviation }\end{array}$ & $\mathbf{1 5 . 4 6 1 3 3}$ & $\mathbf{1 0 . 3 7 1 9 6}$ \\
\hline $\begin{array}{c}\text { Coefficient of } \\
\text { variance }\end{array}$ & $\mathbf{1 3 7 . 5 2}$ & $\mathbf{1 1 0 1 . 0 6 5}$ \\
\hline
\end{tabular}

\section{Source: Authors Compilation}

It is found in Table 1 that among the stocks of $0-1 \mathrm{z}$ score portfolio, Ansal Housing has positive return and Neogem India has the negative return. Even though the standard deviation of Neogem India his higher than the standard deviation of Ansal Housing, Ansal Housing has more coefficient of variance in the returns of the stocks. Therefore it is concluded that Ansal Housing has more return and more risk compared to Neogem India.

It is crystal clear from Table 2 that among the stocks of $1-1.5 \quad \mathrm{z}$ score portfolio, Dynamic industries has positive return and Chromatic India has the negative return. Even though the standard deviation of Dynamic industries is higher than the standard deviation of Chromatic India and Chromatic India has more coefficient of variance in the returns of the stocks. Therefore it is concluded that Chromatic
India has more risk and Dynamic industries has more return.

Table- 2: Risk-return profile of stocks of portfolio with 1 to $1.5 \mathrm{Z}$ value

\begin{tabular}{|c|c|c|}
\hline Month & $\begin{array}{l}\text { ChromaticIn } \\
\text { dia }\end{array}$ & $\begin{array}{c}\text { Dynamicindust } \\
\text { ries }\end{array}$ \\
\hline Mar-14 & -0.526315789 & 69.19934641 \\
\hline Feb-14 & -23.69477912 & 27.89968652 \\
\hline Jan-14 & -28.24207493 & -26.38461538 \\
\hline Dec-13 & 40.48582996 & 14.63844797 \\
\hline Nov-13 & 4.219409283 & 67.75147929 \\
\hline $\begin{array}{l}\text { act- } \\
2013\end{array}$ & 4.635761589 & -8.027210884 \\
\hline Sep-13 & -17.78584392 & 3.521126761 \\
\hline Aug-13 & 31.50357995 & -25.80982236 \\
\hline Jul-13 & -0.238095238 & 9.621993127 \\
\hline Jun-13 & -4.545454545 & -4.590163934 \\
\hline May-13 & -64.94023904 & 5.53633218 \\
\hline Apr-13 & -52.55198488 & 2 \\
\hline $\begin{array}{c}\text { Averag } \\
\text { e }\end{array}$ & -9.30668389 & 11.27971664 \\
\hline $\begin{array}{c}\text { Standa } \\
\text { rd } \\
\text { deviatio } \\
\text { n }\end{array}$ & 30.6102085 & 30.7957165 \\
\hline $\begin{array}{c}\text { co } \\
\text { efficien } \\
t \text { of } \\
\text { varianc }\end{array}$ & 328.9056432 & 273.0185295 \\
\hline
\end{tabular}




$$
\text { e }
$$

\section{Source: Authors Compilation}

Table 3: Risk returns profile of stocks of portfolio with 1.5 to $2 \mathrm{Z}$ value

\begin{tabular}{|c|c|c|}
\hline Month & $\begin{array}{l}\text { Flawless } \\
\text { Diamond }\end{array}$ & DCM \\
\hline Mar-14 & -7.692307692 & -3.94444 \\
\hline Feb-14 & -13.33333333 & 29.40331 \\
\hline Jan-14 & 50 & -0.71378 \\
\hline Dec-13 & 42.85714286 & 2.487198 \\
\hline Nov-13 & -51.72413793 & -1.01376 \\
\hline Oct-13 & 26.08695652 & 1.172161 \\
\hline Sep-13 & 228.5714286 & 0.367647 \\
\hline Aug-13 & -41.66666667 & -2.78771 \\
\hline Jul-13 & -50 & -5.98118 \\
\hline Jun-13 & -7.692307692 & 10.22222 \\
\hline May-13 & -10.34482759 & 0.821509 \\
\hline Apr-13 & -19.44444444 & 9.039088 \\
\hline Average & 12.13479188 & 2.757029 \\
\hline $\begin{array}{l}\text { Standard } \\
\text { deviation }\end{array}$ & 75.79148685 & 9.270869 \\
\hline $\begin{array}{l}\text { Co efficient } \\
\text { of variance }\end{array}$ & 624.5800305 & 336.263 \\
\hline
\end{tabular}

\section{Source: Authors Compilation}

As shown in Table 3 that among the stocks of $1.5-2 \mathrm{z}$ score portfolio, both the stocks have positive returns and Flawless Diamond has higher return than the returns of DCM. DCM has the lowest standard deviation and coefficient of variance. Therefore it is concluded that high returns of Flawless Diamond is accompanied by high risk also.

Table 4:Risk-return profile of stocks of portfolio with 2 and Above $Z$ value

\begin{tabular}{|c|c|c|}
\hline Month & $\begin{array}{c}\text { Classic } \\
\text { Diamond }\end{array}$ & Amal \\
\hline Mar-14 & -1.380670611 & 0.421053 \\
\hline Feb-14 & 2.382875606 & -8.06452 \\
\hline Jan-14 & 24.86132123 & 20.15504 \\
\hline Dec-13 & -3.362573099 & 0.15528 \\
\hline Nov-13 & 65.88520614 & -10.8651 \\
\hline Oct-13 & 35.19125683 & 41.25122 \\
\hline Sep-13 & 8.669833729 & 6.23053 \\
\hline Aug-13 & 50.35714286 & -4.1791 \\
\hline Jul-13 & -11.39240506 & -4.73934 \\
\hline Jun-13 & 26.4 & -10.2128 \\
\hline May-13 & -8.256880734 & -2.08333 \\
\hline Apr-13 & 0.553505535 & -6.25 \\
\hline Average & 15.8257177 & 1.818251 \\
\hline $\begin{array}{l}\text { Standard } \\
\text { deviation }\end{array}$ & 24.71116529 & 15.00894 \\
\hline $\begin{array}{l}\text { co efficient } \\
\text { of variation }\end{array}$ & 156.1456217 & 825.4605 \\
\hline
\end{tabular}

Source: Authors compilation

As shown in Table 4 that among the stocks of 2 and Abovez score portfolio, both the stocks have positive returns and the returns 
of Classic Diamond is higher than the returns of Amal. Even though the standard deviation of Classic Diamond is higher than the standard deviation of Amal andAmal has more coefficient of variance in the returns of the stocks. Therefore it is concluded that Amal has more risk and Classic Diamond has more return.

\begin{tabular}{|c|c|c|c|c|}
\hline $\begin{array}{c}\text { Portf } \\
\text { olio }\end{array}$ & $\begin{array}{c}\text { Returns } \\
\text { of } \\
\text { compan } \\
\mathbf{y} \mathbf{1}\end{array}$ & $\begin{array}{c}\text { Returns } \\
\text { of } \\
\text { compan } \\
\mathbf{y} 2\end{array}$ & $\begin{array}{c}\text { Portf } \\
\text { olio } \\
\text { retur } \\
\mathbf{n}\end{array}$ & $\begin{array}{c}\text { Ra } \\
\mathbf{n k}\end{array}$ \\
\hline $0-1$ & & & - & 4 \\
& -11.243 & 3 & 5 & \\
\hline $1-$ & - & 0.94199 & 5.150 & \\
1.5 & 9.30668 & 11.2797 & 0.986 & \\
\hline $1.5-$ & 12.1347 & 2.75702 & 11.70 & 2 \\
2 & 9188 & 9 & 725 & \\
\hline 2 and & 15.8257 & 1.81825 & 8.821 & 1 \\
above & 177 & 1 & 984 & \\
\hline Source: Auts & 1664 & 516 & \\
\hline
\end{tabular}

\section{Source: Authors Compilation}

Assuming equal proportion of investment each of the stock of each portfolio, the returns of the portfolios are calculated and presented in the above table. The table shows the fact that portfolio with least $\mathrm{Z}$ score has earned the least returns and portfolio with high $\mathrm{Z}$ score has earned highest returns. It is also clear that there is a positive correlation between the $\mathrm{Z}$ Score values and the portfolio returns.

\section{FINDINGS AND SUGGETIONS}

- It is found in the study that among the stocks of $0-1 \mathrm{Z}$ score portfolio, Ansal Housing has positive return and Neogem India has the negative return. Under this portfolio, Ansal Housing has more return and more risk compared to Neogem India.

- It is crystal clear from Table 2 that among the stocks of $1-1.5 \mathrm{z}$ score portfolio, Dynamic industries has positive return and Chromatic India has the negative return. Dynamic Industries is the best security, both in terms of risk and returns.

- It is clear from the study that among the stocks of $1.5-2 \mathrm{Z}$ score portfolio, both the stocks have positive returns and Flawless Diamond has higher return and risk than the returns of DCM. D 
- It is found in the study that among the stocks of 2 and Above $Z$ score portfolio, both the stocks have positive returns and the returns of Classic Diamond is higher than the returns of Amal.

- One of the most important findings of the study is that among the various portfolios constructed based on the financial soundness of the companies, portfolio with highest $\mathrm{Z}$ score has obtained the highest returns and a portfolio with lowest $\mathrm{Z}$ score has obtained the lowest returns. Finally, it can be concluded that the financial strengths and its soundness plays a vital role in the decisions of an investor. Investors prefer stocks of financially sound company. The study proves that the companies with sound financial position will perform better in the stock market than the stocks of financially weak companies. Therefore, it is suggested to the investors that it is better to pick up the stocks of financially sound companies so as to have higher returns for lesser risk in their investment.

\section{BIBLIOGRAPHY:}

Agrawal, N.P, ( 1983) Analysis of Financial Statements. National Publishing House. New Delhi

Avadhani V.A.(2011), Security Analysis and Portfolio Management, Himalaya Publishing House.

Balla V. K. (2002), Portfolio Analysis and Management, Sulthan Chand and Co. Ltd., New Delhi.

BhatSudhindra (2008), Security Analysis and Portfolio Management, Excel Books, New Delhi.

Brigham E F and Gapenski L C (1991), Financial Management: Theory and Practice, 6th Edition, The Dryden Press, Orlando, Fl.

Chandra Prasanna (2008), Investment Analysis and Portfolio Management, $3^{\text {rd }}$ edition, Tata McGraw Hill, New Dehi.

Chandra Prasanna (2010),Fundamentals of Financial Management, Tata McGraw Hill Education Pvt. Ltd., New Delhi

Fisher. E. Donald and Jordan. J. Ronald (2006), Security Analysis and Portfolio Management, Pearson Prentice Hall.

Kevin. S (2008), Portfolio Management, $2^{\text {rd }}$ edition, PHI Learning Pvt. Ltd, New Delhi. 
Asia Pacific Journals

Khan M Y and Jain P K, (2010) Financial Management, Fifth edition, Tata McGraw -

Hill, New Delhi

Kuchhal, $\quad$ S.C.,(1985), $\quad$ Financial

Management, Chitanya Publishing,

Allahabad.

Kulkarni,P.V., Sathya Prasad B.G.(1999),

Financial Management, Himalaya

Publishing, Bombay.

Maheshwari S N (1996), Management

Accounting and Financial Control, Sultan

Chand \& Sons, New Delhi.

Nagarajan K and JayabalG(2011), Security Analysis and Portfolio Management, New Age International.

Pandey I. M, (2004) Financial Management, Ninth edition, Vikas Publishing House, New Delhi

Pandian Punithavathy (2004), Security Analysis and Portfolio Management, Vikas Publishing House Pvt. Ltd, New Delhi. Van Horne J C and Wachowicz J M (2004), Fundamentals of Financial Management, 12th Edition, Prentice Hall Publishers, New York 